\title{
An Ungrateful Disposition: Psychometric Properties of the Dispositional Envy Scale in Brazil
}

\author{
Emerson Diógenes de Medeiros ${ }^{1}$ \\ Universidade Federal do Piauí, \\ Parnaíba-PI, Brazil
}

\author{
Ana Karla Silva Soares \\ Universidade Federal do Mato Grosso \\ do Sul, Campo Grande-MS, Brazil
}

\author{
Anderson Mesquita do Nascimento \\ Universidade Federal da Paraíba, \\ João Pessoa-PB, Brazil
}

\author{
Jéssica Bruna Santana Silva \\ Universidade Federal da Paraíba, \\ João Pessoa-PB, Brazil
}

\author{
Valdiney Veloso Gouveia \\ Universidade Federal da Paraíba, \\ João Pessoa-PB, Brazil
}

\begin{abstract}
Envy appears to be found among all cultures, and most individuals seem capable of experiencing it. The aim of this research was to gather evidence of the validity and reliability of the Brazilian version of the Dispositional Envy Scale. For that, we performed two studies, each with 246 university students. In the first study, the results indicated that the instrument is composed of a single component. The second study confirms this structure based on the good fit indices and presents adjustment indicators that comply or approach the recommended criteria in the literature. Both studies demonstrate that the single component instrument presents a good level of reliability, as indicated by levels of internal consistency and homogeneity that exceed those recommended for such studies. Accordingly, it was concluded that the Brazilian-Portuguese version of the Dispositional Envy Scale presents acceptable psychometric characteristics and that it may, therefore, be used to assess the tendency or predisposition to feel envy.
\end{abstract}

Keywords: envy, test validity, test reliability, scaling (testing)

\section{Uma Disposição Ingrata: Propriedades Psicométricas da Escala de Inveja Disposicional no Brasil}

\begin{abstract}
Resumo: A inveja parece ser encontrada em todas as culturas, e a maioria das pessoas parecem capazes de senti-la. O objetivo deste estudo foi reunir evidências de validade e confiabilidade da versão brasileira da Escala de Inveja Disposicional. Para tanto se procedeu dois estudos, cada um com 246 estudantes universitários. No primeiro estudo os resultados mostraram que o instrumento é formado por um único componente. O segundo estudo confirmou esta estrutura, como pode ser observado nos índices de ajuste adequados, os quais apresentaram indicadores de ajuste que cumprem ou se aproximam dos critérios recomendados na literatura. Ambos os estudos demonstraram que o componente único apresentou bom nível de confiabilidade, o que foi observado pelos altos índices de consistência interna e homogeneidade, acima do recomendado para realização de pesquisas. Portanto, conclui-se que a versão brasileira da Escala de Inveja Disposicional apresenta características psicométricas bastante aceitáveis, e pode ser usada para avaliar tendências a sentir inveja.
\end{abstract}

Palavras-chave: inveja, validade do teste, precisão do teste, escalas

\section{Una Disposición Ingrata: Propiedades Psicométricas de la Escala de Envidia Disposicional en Brasil}

\begin{abstract}
Resumen: La envidia parece encontrarse en todas las culturas, y la mayoría de la gente parece capaz de sentirlo. El objetivo de este estudio fue reunir evidencias de validez y fiabilidad de la versión brasileña de la Escala de Envidia Disposicional. A este fin fueron desarrollados dos estudios, cada uno con 246 estudiantes universitarios. En el primer estudio, los resultados mostraron que el instrumento es compuesto de un componente. El segundo estudio confirmó esta estructura, como se observa en los índices de ajuste apropiados, que mostró indicadores de ajuste que cumplen o se acercan a los criterios recomendados en la literatura. Ambos estudios mostraron que el único componente presentó un buen nivel de fiabilidad, observado por los altos índices de consistencia interna y homogeneidad, además del recomendado para el desarrollo de investigaciones. Así, se concluye que la versión brasileña de la Escala de Envidia Disposicional presenta características psicométricas bastante aceptables y puede ser utilizada para evaluar las tendencias para sentir envidia.
\end{abstract}

Palabras clave: envidia, validación de test, precisión de test, escalas

Envy, as a feeling, appears to be found among all cultures throughout the world, and most individuals seem capable

\footnotetext{
${ }^{1}$ Correspondence address:

Emerson Diógenes de Medeiros. Universidade Federal do Piauí, Campus Ministro Reis Veloso, Departamento de Psicologia. Av. São Sebastião, 2819. Bairro Nossa Senhora de Fátima. CEP 64202-020. Parnaíba-PI, Brazil. E-mail: emersondiogenes@gmail.com
}

of experiencing and feeling envy. Envy, which typically involves two people, refers to the feelings aroused when one person wishes to have an advantage over another or desires that which someone else has. Many studies have investigated why people feel envious of others and take into account that it is likely that there are important individual differences in the propensity to experience envy (Smith, Parrott, Diener, 
Hoyle, \& Kim, 1999). Moreover, envy is mentioned in early religious writings. For instance, the Catholic religion regards envy as a deadly sin, and as such, it is represented in the story of Cain and Abel, wherein Cain's murder of Abel was motivated by envy, and in fictional portrayals of characters who are consumed by envy. While these depictions explicitly convey individual differences in predispositions to experience envy, these depictions may also contribute to the negative view society has toward envy as an emotional trait (Lange \& Crusius, 2015).

In this sense, envy may be defined as a negative emotional response to another person's superior qualities, characteristics, achievements or possessions in which the envier either desires the superior advantage or wants that which the envied person has (Smith \& Kim, 2007) and is associated with the motivation to improve oneself by moving upward (Crusius \& Lange, 2014). Thus, in principle, envy is based on upward social comparisons (Lange \& Crusius, 2015), which are a fundamental element of human cognition. The fact that people engage in social comparisons habitually and automatically explains why envy is such a common and culturally universal feeling (Corcoran, Crusius, \& Mussweiler, 2011).

Oftentimes, envy is confused with jealousy. There is, however, a fine distinction between the two in that the former involves two people and corresponds to the manifestation of feelings when a person wishes to gain an advantage over another, while the latter involves three people and refers to the feelings aroused when a person fears losing a special relationship with a rival (Epstein, 2006). These terms, however, are often mistaken due to the semantic ambiguity regarding the way in which the word "jealousy" is used in English and because of the frequent occurrence of these two emotions, either simultaneously or separately (Parrott \& Smith, 1993).

Nevertheless, some countries have semantic distinctions that suggest the existence of other forms of envy, such as the Russian terms for black and white envy. In other cases, there may be an inclusive word, for example, the German terms neid (envy) and missgönnen (envious) correspond to both forms of envy (black and white). In contrast, languages such as English, Portuguese and Spanish have only one word for envy. Regardless of when speakers of these languages are asked to provide an example about each type of envy, they report one of two qualitatively distinct emotional episodes that matches the distinction between benign (white) and malicious (black) envy (Crusius \& Lange, 2014; van de Ven, Zeelenberg, \& Pieters, 2009).

Consistent with this distinction, van de Ven et al. (2009), in an investigation about envy and envious people, revealed that there is a benign kind of envy that influences upward motivation by increasing the desire to obtain what the envied person has yet lacks the hostility present in malicious envy. At the same time, benign enviers may try to level the differences between themselves and the object of their envy by improving their own situation or status. This perspective is supported by research that finds that envy can promote behavior aimed toward obtaining a desired object (Crusius
\& Mussweiler, 2012) and shift attention toward the means to attain that object (Crusius \& Lange, 2014). These findings suggest that envy-eliciting contexts result in benign envy if the envied person's advantage is evaluated as subjectively merited (van de Ven et al., 2012).

On the other hand, malicious enviers focus on lowering the envied person's status or position by denigrating the object of their envy and decreasing the advantage of the envied person. Indeed, some studies have indicated that envy can increase the positive affect arising from the satisfaction felt when the goal of reducing the status of the object of their envy is attained (van de Ven et al., 2014), it can induce hostile and resentful behaviors (Duffy, Scott, Shaw, Tepper, \& Aquino, 2012), and it can shift attention toward the object of their envy (Hill, DelPriore, \& Vaughan, 2011). In this sense, envy-eliciting situations cause malicious envy if the envied person's advantage is evaluated as subjectively unmerited (van de Ven et al., 2012).

Furthermore, it has been determined that envy is composed of two principal affective components: hostility and depression (Smith, Parrott, Ozer, \& Moniz, 1994). The hostility component is linked to feelings of ill will and anger that result from subjective beliefs that an injustice has occurred whereas the depressive component is related to feelings of inferiority that result from unfavorable social comparisons. Considering that social comparisons affect personal assessments regarding the person who is experiencing envy, such comparisons can also affect the person's self-esteem and thus cause the that person to express unhappiness with his/her life (Tesser, 1991). Thus, for those who are more inclined to experience envy and who exhibit characteristics of high dispositional envy, social comparisons often lower their self-esteem and cause them to perceive themselves as inferior (Milfont \& Gouveia, 2009).

Several studies have found that envy arises when one compares his/her personal outcomes and achievements to the superior outcomes and achievements of others and that, accordingly, it is linked to feelings of inferiority (e.g., low selfesteem, depression, neuroticism, jealousy). Similarly, envy is linked to feelings of pleasure when the envied person suffers a setback, to a sense of justice relative to the disadvantaged position, even when the envy is subjective (Parks, Rumble, \& Posey, 2002; Smith et al., 1994), and to feelings of ill will (e.g., hostility and resentment). Moreover, envy is also negatively associated with a sense of wellbeing (e.g., life satisfaction, happiness) (Milfont \& Gouveia, 2009; Smith et al., 1999). Thus, based on the research, it is concluded that envy is an important emotion present in human interactions, and thus, it is important that it be assessed correctly, by using instruments with acceptable psychometric properties. The extant literature suggests that the most commonly used scale to assess envy is the Dispositional Envy Scale (DES).

The Dispositional Envy Scale is a measure that aims to assess tendencies or predispositions to feel and experience envy. This scale is an eight-item self-report measure developed by Smith et al. (1999) and is administered to several samples in the U.S. According to Lange and Crusius (2015), this measure has to be adequate to measure 
dispositional malicious envy, being associated with the active disengagement of concrete goals. An investigation of the instrument's factorial validity revealed that the item total correlations ranged from .48 to .71 , whereas an assessment of the instrument's reliability revealed alphas ranging from .83 to .86 in the several samples studied. Furthermore, the testretest reliability measurement was .80 , wherein the retest was administered two weeks after the initial test. The authors also tested different factor structures using confirmatory factor analysis (CFA) and found that the items on the DES were well represented by a single construct. Milfont and Gouveia (2009), in the first attempt to assess the validity and internal reliability of the Brazilian version of the DES, found factor loadings ranging from .45 to .73 and item-total correlations ranging from .31 to .59 . With respect to internal consistency, the coefficient alpha was .79, indicating that the DES has high internal consistency. A confirmatory analysis also supported the single component structure, with loadings ranging from .39 to .68 , and supported the satisfactory fit indices following the inspection of the modifications indices, which indicated that Item 2 and Item 6 as well as Item 7 and Item 8 share common error variances.

Although there is evidence of validity and reliability in Brazil reported by Milfont and Gouveia (2009), it is noted that these authors did not use adequate sample sizes to serve the purpose of verifying the psychometric adequacy of the DES in the Brazilian context, a factor that reinforces the importance of this study, using different samples. Thus, this manuscript aims to present psychometric evidence of the Dispositional Envy Scale, and to do so, two studies were conducted.

\section{Method - Study 1}

\section{Exploratory Analysis of the Dispositional Envy Scale (DES)}

The goal of Study 1 was to provide a preliminary test to verify whether the Dispositional Envy Scale shows evidence of construct validity and internal consistency based on a sample of university students.

\section{Participants}

Participants included 246 university students from the state of Paraiba, Brazil. Most participants were female (66.3\%) and single (85.6\%). The mean participant age ranged from 16 to 57 years $(M=21.9, S D=6.27)$. As a convenience sampling (nonprobabilistic) technique was employed, the subjects consisted of those who were present in class and who agreed to participate on the day the questionnaire was administered.

\section{Instruments}

The participants were given a paper-pencil version of the Dispositional Envy Scale, which is an eight-item self-report measure developed by Smith et al. (1999) and validated for Brazil by Milfont and Gouveia (2009) to assess tendencies to feel envy (e.g., "I feel envy every day; the bitter truth is that I generally feel inferior to others"). The DES was rated using a 5-point Likert-type scale that ranged from 1 (strongly disagree) to 5 (strongly agree). Participants also answered questions regarding personal demographics (sex, age, educational level and marital status).

\section{Procedure}

Data collection. The DES was administered during class by two trained researchers. The students individually completed the questionnaire in a collective classroom environment. Student participation was voluntary, and the average time to complete the instrument was 15 minutes.

Data analysis. The ' $R$ ' statistical program was used to analyze the data (R Development Core Team, 2011). First, the descriptive statistics were observed, and the discrimination power of items was evaluated using the multivariate analysis of variance (MANOVA). Second, the adequacy of the inter-item correlation matrix for use in the factorial analysis was examined, and the Kaiser-MeyerOlkim (KMO) criterion with a minimum value of .60 was evaluated using the Psych statistical package (Revelle, 2014). The Bartlett sphericity test was conducted using the Corpcor statistical package (Schäfer et al., 2013), wherein a statistically significant $\chi^{2}$ was required for subsequent analysis (Tabachnick \& Fidell, 2013).

A principal components (PC) analysis was conducted to investigate the measure's structure. To observe the number of components to be extracted, a PC analysis was conducted on five criteria: Kaiser values, Cattell criterion, parallel analysis, acceleration factor and optimal coordinates (Hayton, Allen, \& Scarpello, 2004; Pasquali, 2010; Raiche, Walls, Magis, Riopel, $\&$ Blais, 2013). These analyses were performed using the Psych and nFactors statistical packages (Raiche \& Magis, 2014; Revelle, 2014). Finally, to observe the internal consistency of components according to the PC analysis, the Cronbach's alpha index was evaluated using the Psych package.

\section{Ethical Considerations}

The study was approved by the Ethics Committee on Human Research of the Medical Sciences Faculty of the Universidade Federal da Paraíba (n. 1.176.964) in accordance with the Brazilian National Health Council (Resolution n. 466/12). The students were informed of the objectives and were guaranteed anonymity and confidentiality with respect to the study.

\section{Results}

Initially, the MANOVA was implemented to verify whether the items had the capacity to differentiate among respondents with close magnitudes. The respondents were separated into an upper and a lower group, using the empirical median as a basis (half of the total score above and half below the median), thus forming two criteria groups. For each item, the MANOVA was used to compare the means of the participants from the two groups for all items. The results indicate that there were differences between the groups [Wilks' Lambda $=.38 ; F(8,235)=47.01, p<.001$ ] 
Specifically, it was determined that all items satisfactorily discriminated between the two groups $(\mathrm{F}>50.47, p<.001)$, being the item 6 the most discriminative $\left(\eta^{2}=.38\right)$ and the item 8 the least $\left(\eta^{2}=.18\right)$.

Following the MANOVA, the viability of performing a principal components (PC) analysis was assessed. The results corroborated the adequacy of the correlation matrix $\left[\mathrm{KMO}=.83\right.$; Bartlett sphericity test $\chi^{2}(28)=804.37$, $p<.001]$. To evaluate the dimensionality of the DES, a PC analysis without fixing rotation was conducted. The Kaiser values suggested a solution with two components (eigenvalues $=4.02,1.07$ ), while the graphic distribution of eingenvalues (Cattell criterion) suggested that one component should be extracted. Considering the limitations of these last extraction methods and given that Kaiser values tend to overestimate the number of components and the Cattell criterion may be ambiguous, a parallel analysis with 1,000 random databases simulating this research was performed. The result supports the existence of a onecomponent solution, as the value of the second component in the parallel analysis (1.17) was greater than the second eigenvalue with respect to the KMO criterion (1.07).

To provide further evidence of the factorial structure, two non-graphic alternatives, which aimed to overcome the limitations of subjectivity inherent to the scree test, were conducted. The optimal coordinates factor analysis was conducted to determine the location of the scree by measuring the gradients associated with the eigenvalues and their preceding coordinates. Additionally, the acceleration factor aims to ascertain the point at which the slope of the curve changes most abruptly (Raiche \& Magis, 2014). The graphic distribution (scree plot) of all criteria values is presented in Figure 1.

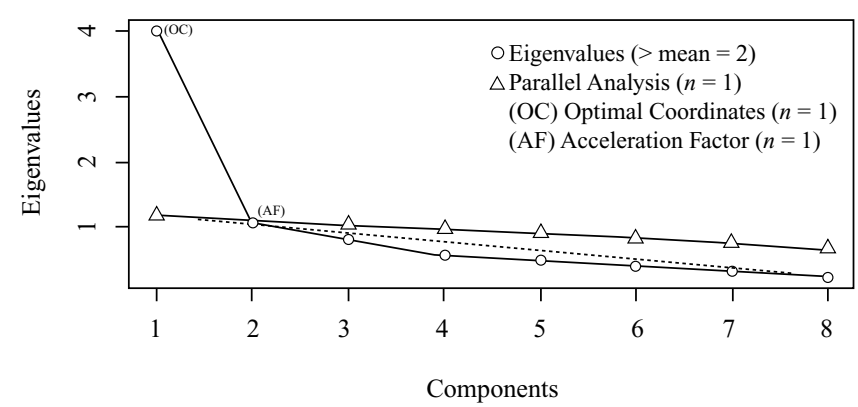

Figure 1. Graphical distribution of the eigenvalues.

As shown, four of the five criteria used to determine the factorial structure of the DES support the existence of a single component, and thus, this structure was adopted for further analysis. The purpose of this step was to evaluate the internal consistency and saturations of the items using $|.30|$ as a cut-point for each item to be retained in the component. The resulting structure is presented in Table 1.

Table 1

Factorial Structure of the Dispositional Envy Scale

\begin{tabular}{lll}
\hline Item & Factor & $\mathrm{h}^{2}$ \\
\hline 3. Feelings of envy constantly torment me & .80 \\
[Sentimentos de inveja me atormentam constantemente] & .64 \\
5 . No matter what I do, envy always plagues me & .76 \\
[Não importa o que eu faça, a inveja sempre me atormenta] & .58 \\
8. Frankly, the success of my neighbors makes me resent them & .74 \\
[Francamente, o sucesso dos meus vizinhos me faz sentir mal e ofendido em relação a eles] & .54 \\
6. I am troubled by feelings of inadequacy & .72 \\
[Eu vivo preocupado/a por sentimentos de incapacidade e inferioridade] & .52 \\
1. I feel envy everyday & .68 \\
[Eu sinto inveja diariamente] & .46 \\
4. It is so frustrating to see some people succeed so easily \\
[É muito frustrante ver algumas pessoas terem sucesso tão facilmente] \\
2. The bitter truth is that I generally feel inferior to others \\
[A pior verdade é que eu geralmente me sinto inferior em relação as outras pessoas] \\
7. It somehow doesn't seem fair that some people seem to have all the talent \\
[De certo modo não parece justo que algumas pessoas tenham todo o talento]
\end{tabular}

According to Table 1, saturation points ranged from .80 (Item 3) to .62 (Item 7). That is, all of them showed minimal saturations to be retained in the component. Furthermore, the single component presented an eigenvalue of 4.02, which explained $50.4 \%$ of the total variance. Its coefficient of internal consistency (Cronbach's alpha) was .84, and the values of alpha when the item is dropped indicate that none of the items would increase the reliability if it was deleted. Homogeneity was calculated by the average correlation of inter-items $\left(r_{i . i}=.44\right)$.

\section{Partial Discussion}

The aim of this study was to seek evidence of factorial validity and internal consistency of the Dispositional Envy Scale. The results show a unidimensional factor structure that is consistent with the previous studies of development (Smith et al., 1999) and with the Brazilian adaptation (Milfont \& Gouveia, 2009). The results further indicate that all items of the DES showed satisfactory discrimination power, high 
saturations in a single component and acceptable internal reliability, as Cronbach's alpha was approximately the same as it was in the original study (Smith et al., 1999) and was higher than that of the first Brazilian adaptation study (Milfont \& Gouveia, 2009). Furthermore, the results indicate that the DES has good homogeneity, and consequently, the results support its construct validity. However, to obtain further evidence that support the determined structure, a confirmatory factor analysis (CFA) was conducted, as such an analysis offers robust indices that permit assessing the model fit to the data (Tabachnick \& Fidell, 2013).

\section{Method - Study 2}

\section{Confirmatory Analysis of the Dispositional Envy Scale (DES)}

In this second study, a confirmatory analysis was performed to complement the results of Study 1. Specifically, we analyzed the factor structure of the Dispositional Envy Scale through structural equation modeling. This procedure permits a more robust conclusion regarding the factorial validity of the measure and also indicates how the empirical data fit the theoretical model.

\section{Participants}

The participants included 246 undergraduates from the Brazilian state of Paraíba, Brazil whose ages ranged from 16 to 48 years $(M=21.3, S D=5.78)$. The majority of the participants were female (68.7\%) and single (87.1\%). This was a convenience sample (nonprobabilistic), i.e., the subjects were those who were present in class on the day of data collection and who agreed to participate in the research.

\section{Procedure}

Data collection. Participants received a printed questionnaire regarding demographic information (age, sex and marital status) and the Dispositional Envy Scale (described in Study 1) and followed the same instructions as per the application procedure. The average time of participation was 15 minutes.

Data analysis. Data were analyzed with SPSS software (18th version), and the descriptive statistics and internal consistency (Cronbach's alpha) were calculated. Composite reliability (CC) was also calculated, and values above .70 were considered as evidence of acceptable reliability (Fornell \& Larcker, 1981). The AMOS (18th version) program was used to establish the factor structure of the scale, wherein the covariance matrix was used as input assuming the maximum likelihood (ML) estimator. To ascertain the quality of adjustment of the model tested, certain indicators of adjustment were taken into account, such as the Chi-square statistic $\left(\chi^{2}\right.$ - ideal nonsignificant, $\left.p>.001\right) ; \chi^{2} / d f$ ratio in the range between 2 and 3; goodness of fit index (GFI; values ranging from 0 to 1 where those close to or above .90 represent a very good fit); comparative fit index (CFI; values close to or above .90 indicate a very good fit); Tucker-Lewis index (TLI; indicators close to 1.00 and assuming values between .80 and .90 indicate a very good fit); the standardized root mean square residual (SRMR; values less than .10, and preferably less than .08, are considered a good fit); and root mean square error of approximation (RMSEA; values between .05 and .08 are recommended, although values less than .10 are considered satisfactory; Hair, Black, Babin, Anderson, \& Tatham, 2009; Hooper, Coughlan, \& Mullen, 2008; Hu \& Bentler, 1998; Tabachnick \& Fidell, 2013).

\section{Ethical Considerations}

In accordance with the Brazilian National Health Council (Resolution n. 466/12), the students were informed of the objectives, were guaranteed anonymity and confidentiality with respect to the study. The participant could withdraw from the study at any time without being penalized. The information regarding this study's approval had been presented beforehand.

\section{Results}

Considering the structure observed by Milfont and Gouveia (2009), and in accordance with the findings of Study 1, the factor structure of the Dispositional Envy Scale was tested with the eight items loading on the same general factor. The following adjustment indicators were obtained for the estimator ML: $\chi^{2}(20)=241.73, p<.001$; $\chi^{2} / d f=12.08 ; \mathrm{GFI}=.81 ; \mathrm{AGFI}=.65 ; \mathrm{CFI}=.77 ; \mathrm{TLI}=.68$; RMSEA $=.213,90 \%$ CI $[.189, .237]$; and SRMR $=.06$. However, it was decided to re-specify the model, considering the MIs (modification indices). These indices indicated shared common error variance between Item 2 ("The bitter truth is that I generally feel inferior to others") and Item 6 ("I am troubled by feelings of inadequacy"), with an MI = 98.26 and between Item 4 ("It is so frustrating to see some people succeed so easily") and Item 7 ("It somehow does not seem fair that some people seem to have all the talent"), with an $\mathrm{MI}=22.73$. After allowing the errors to covariate, the indices indicated a better fit of the data: ML: $\chi^{2}(18)=$ $92.15, p<.001 ; \chi^{2} / d f=5.12 ; \mathrm{GFI}=.91 ; \mathrm{CFI}=.92 ; \mathrm{TLI}=.88$; RMSEA $=.130,90 \%$ CI $[.104, .156]$; and SRMR $=.06$. The corresponding factor structure is presented in Figure 2.

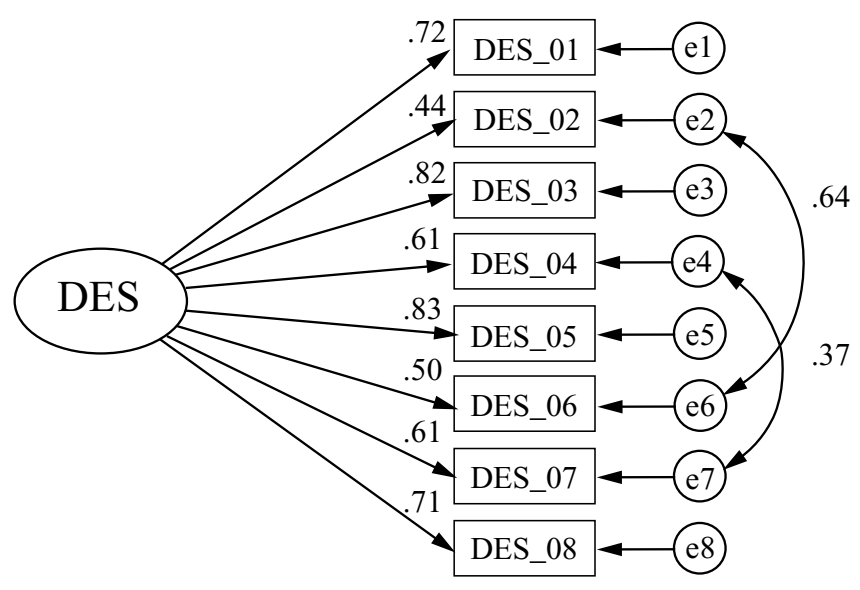

Figure 2. Factor structure of the Dispositional Envy Scale (DES). 
The factor weights (Lambdas) were all positive and significantly different from zero $(\lambda \neq 0 ; z>1.96, p<.001)$, ranging from .44 (Item 2: "The bitter truth is that I generally feel inferior to others") to .83 (Item 5: "No matter what I do, envy always plagues me"), with a mean of .65. Indicators of internal consistency included Cronbach's alpha $(\alpha=.86)$, homogeneity (average correlation inter-items, $r_{\mathrm{i}, \mathrm{i}}=.46$ ) and composite reliability $(\mathrm{CC}=.91)$. These indices provide satisfactory evidence of internal consistency.

\section{Partial Discussion}

This study aimed to identify more robust evidence regarding the factor structure and internal consistency of the DES. To do so, it was necessary to re-specify the model considering modification indices, a procedure that has been conducted in other studies (Milfont \& Gouveia, 2009; Smith et al., 1999). Specifically, items 2 and 6 also shared common variance with other studies (Milfont \& Gouveia, 2009), providing empirical support to confirm the modification. Finally, the multiple indicators of homogeneity were found to be satisfactory, as evidenced by the fact that the values exceeded those recommended for Cronbach's alpha (Pasquali, 2010), homogeneity (Clark \& Watson, 1995) and composite reliability (Hair et al., 2009). Moreover, the results confirmed the validity of the eight-item scale factor structure, which presented adjustment indicators that complied with the recommended criteria in the literature, except RMSEA which was close to that recommended by the literature (.10; Tabachnick \& Fidell, 2013).

\section{General Discussion}

Envy is an emotion characterized by an intense coveting for that which another person has (Smith \& Kim, 2007), and social life presents us with a wealth of opportunities to covet what others have (Rodriguez Mosquera, Parrott, \& Hurtado de Mendoza, 2010). In essence, envy is based on an upward social comparison and a subjective sense of injustice, which are related to feelings of ill will and feelings of inferiority, respectively (Smith et al., 1999). Thus, as dispositional envy can determine important psychological and behavioral results, it is important to assess this construct using instruments with acceptable psychometric properties.

Literature demonstrates that the envy can be studied by two perspectives: the benign and malicious (Crusius \& Lange, 2014; Lange \& Crusius, 2015). The former is characterized by the influence in upward motivation by increasing the desire to obtain what the envied person has, while the latter focus on lowering the envied person's status or position by denigrating the object of their envy and decreasing the advantage of the envied person. Is necessary to highlight that the instrument used in this research only measures the malicious envy (Lange \& Crusius, 2015), therefore the results discussed are addressed only to this perspective.

The aim of this research was to gather evidence of the validity and reliability of the Brazilian version of the
Dispositional Envy Scale developed by Smith et al. (1999), a scale that assesses tendencies to feel envy. As a review of the extant literature revealed that there is no other instrument designed to measure envy in the Brazilian context, taking into account the psychometric parameters of the scale as studied herein increases the relevance of the findings. In the first study, four of five criteria used indicated the existence of a single component in the DES, the same structure found in other studies (Milfont \& Gouveia, 2009; Smith et al., 1999). In the second study, the findings revealed that a one-factor structure adequately fits the data, as noted in the high factor weights of items and in the fit indices, of which the majority were acceptable, or sufficiently close, to recommend cutoffs, as in case of RMSEA (Hair et al., 2009). Both studies demonstrated that a single component measurement tool presents a good level of reliability, as supported by the levels of internal consistency and homogeneity that exceeded those recommended for research (Pasquali, 2010).

While Milfont and Gouveia (2009) have analyzed the psychometric parameters of the DES within a Brazilian context, they not only used a small sample size $(N=103)$, but they also used the same sample to conduct exploratory and confirmatory factor analyses. In contrast, this research considered a larger sample size and used different samples for the exploratory and confirmatory analyses, a factor that resulted in better than, albeit similar to, the indices of Milfont and Gouveia (2009), thereby providing additional evidence of the construct validity and reliability. Therefore, it is concluded that the Brazilian-Portuguese version of the DES presents acceptable psychometric characteristics and that it may be used to assess the tendency to experience envy.

Thus, one can be confident that the goals of this study have been achieved. Nonetheless it is important to consider certain limitations, which can be subjects for future studies in this field. Specifically, the samples considered are not probabilistic as most were composed of university students, which means the results cannot be extended to the entire Brazilian population. Thus, further studies are needed to attend to this purpose. However, as the primary objective focused on investigating the psychometric parameters of the DES, the sample herein $(n>200)$ is adequate (Hair et al., 2009). Future studies should consider more heterogeneous samples to ascertain whether dispositional envy can vary in function based on sociodemographic variables (e.g., age, gender, cultural groups, and degree of religiosity).

Considering that the DES only evaluates the dispositional malicious envy, future studies to check whether there is a difference between distinct forms of envy (benign and malicious) with samples from Brazil is necessary, since this did not aim of this research. Alternatively, it is recommended that the criterion-related validity with measures of related constructs, such as self-esteem, social desirability (Smith et al., 1999), hostility (Duffy et al., 2012) and beliefs of a just world (Gouveia, Pimentel, Coelho, Maynart, \& Mendonça, 2010), be investigated. Thus, envy is a pan-cultural phenomenon that is deeply rooted in social comparison processes, and most individuals are capable of feeling it. Moreover, it is considered an important emotion that is present in human social interactions. 


\section{References}

Clark, L. A., \& Watson, D. (1995). Constructing validity: Basic issues in objective scale development. Psychological Assessment, 7(3), 309-319. doi:10.1037/10403590.7.3.309

Corcoran, K., Crusius, J., \& Mussweiler, T. (2011). Social comparison: Motives, standards, and mechanisms. In D. Chadee (Ed.), Theories in social psychology (pp. 119139). Oxford, UK: Wiley-Blackwell.

Crusius, J., \& Lange, J. (2014). What catches the envious eye? Attentional biases within malicious and benign envy. Journal of Experimental Social Psychology, 55, 1-11. doi:10.1016/j.jesp.2014.05.007

Crusius, J., \& Mussweiler, T. (2012). When people want what others have: The impulsive side of envious desire. Emotion, 12(1), 142-153. doi:10.1037/a0023523

Duffy, M. K., Scott, K. L., Shaw, J. D., Tepper, B. J., \& Aquino, K. (2012). A social context model of envy and social undermining. Academy of Management Journal, 55(3), 643-666. doi:10.5465/amj.2009.0804

Epstein, J. (2006). Envy: The seven deadly sins. New York, NY: Oxford University Press.

Fornell, C., \& Larcker, D. F. (1981). Evaluating structural equation models with unobservable variables and measurement error. Journal of Marketing Research, 18(1), 39-50. doi:10.2307/3151312

Gouveia, V. V., Pimentel, C. E., Coelho, J. A. P. M., Maynart, V. A. P., \& Mendonça, T. S. (2010). Validade fatorial confirmatória e consistência interna da Escala Global de Crenças no Mundo Justo-GJWS. Interação em Psicologia, 14(1), 21-29. doi:10.5380/psi.v14i1.12687

Hair, J. F., Jr., Black, W. C., Babin, B. J., Anderson, R. E., \& Tatham, R. L. (2009). Análise multivariada de dados [Multivariate data analysis] (A. S. Sant'Anna, Trans. 6th ed.). Porto Alegre, RS: Bookman.

Hayton, J. C., Allen, D. G., \& Scarpello, V. (2004). Factor retention decisions in exploratory factor analysis: A tutorial on parallel analysis. Organizational Research Methods, 7(2), 191-205. doi:10.1177/1094428104263675

Hill, S. E., DelPriore, D. J., \& Vaughan, P. W. (2011). The cognitive consequences of envy: Attention, memory, and self-regulatory depletion. Journal of Personality and Social Psychology, 101(4), 653-666. doi:10.1037/ a0023904

Hooper, D., Coughlan, J., \& Mullen, M. R. (2008). Structural equation modelling: Guidelines for determining model fit. The Electronic Journal of Business Research Methods, 6(1), 53-60.

Hu, L.-T., \& Bentler, P. M. (1998). Fit indices in covariance structure modeling: Sensitivity to underparameterized model misspecification. Psychological Methods, 3(4), 424-453. doi:10.1037/1082-989X.3.4.424

Lange, J., \& Crusius, J. (2015). Dispositional envy revisited: Unraveling the motivational dynamics of benign and malicious envy. Personality and Social Psychology
Bulletin, 41(2), 284-294. doi:10.1177/0146167214564959

Milfont, T. L., \& Gouveia, V. V. (2009). A capital sin: Dispositional envy and its relations to wellbeing. Revista Interamericana de Psicología, 43(3), 547-551.

Parks, C. D., Rumble, A. C., \& Posey, D. C. (2002). The effects of envy on reciprocation in a social dilemma. Personality and Social Psychology Bulletin, 28(4), 509520. doi:10.1177/0146167202287008

Parrott, W. G., \& Smith, R. H. (1993). Distinguishing the experiences of envy and jealousy. Journal of Personality and Social Psychology, 64(6), 906-920. doi:10.1037/00223514.64.6.906

Pasquali, L. (2010). Instrumentação psicológica: Fundamentos e práticas [Psychological instrumentation: Principles and practices]. Porto Alegre, RS: Artmed.

R Development Core Team. (2011). R: A language and environment for statistical computing. Vienna, Austria: R Foundation for Statistical Computing.

Raiche, G., \& Magis, D. (2014). Package 'nFactors': Parallel analysis and non graphical solutions to the Cattell scree test. Retrieved from http://cran.r-project.org/web/ packages/nFactors/nFactors.pdfhttp://cran.r-project.org/ web/packages/nFactors/nFactors.pdf

Raiche, G., Walls, T. A., Magis, D., Riopel, M., \& Blais, J.-G. (2013). Non-graphical solutions for Cattell's scree test. European Journal of Research Methods for the Behavioral and Social Sciences, 9(1), 23-29. doi:10.1027/16142241/a000051

Revelle, W. (2014). Package psych: Procedures for psychological, psychometric, and personality research. Retrieved from http://cran.r-project.org/web/packages/ psych/psych.pdf

Rodriguez Mosquera, P. M., Parrott, W. G., \& Hurtado de Mendoza, A. (2010). I fear your envy, I rejoice in your coveting: On the ambivalent experience of being envied by others. Journal of Personality and Social Psychology, 99(5), 842-854. doi:10.1037/a0020965

Schäfer, J., Opgen-Rhein, R., Zuber, V., Ahdesmäki, M., Silva, A. P. D., \& Strimmer, K. (2013). Package 'corpcor': Efficient estimation of covariance and (partial) correlation. Retrieved from http://cran.r-project.org/web/ packages/corpcor/corpcor.pdf

Smith, R. H., \& Kim, S. H. (2007). Comprehending envy. Psychological Bulletin, 133(1), 46-64. doi:10.1037/00332909.133.1.46

Smith, R. H., Parrott, W. G., Diener, E. F., Hoyle, R. H., \& Kim, S. H. (1999). Dispositional envy. Personality and Social Psychology Bulletin, 25(8), 1007-1020. doi:10.1177/01461672992511008

Smith, R. H., Parrott, W. G., Ozer, D., \& Moniz, A. (1994). Subjective injustice and inferiority as predictors of hostile and depressive feelings in envy. Personality and Social Psychology Bulletin, 20(6), 705-711. doi:10.1177/0146167294206008

Tabachnick, B. G., \& Fidell, L. S. (2013). Using multivariate statistics (6th ed.). Boston, MA: Allyn and Bacon. 
Tesser, A. (1991). Emotion in social comparison and reflection processes. In J. Suls \& T. A. Wills (Eds.), Social comparison: Contemporary theory and research (pp. 115-145). Hillsdale, NJ: Lawrence Erlbaum.

van de Ven, N., Hoogland, C. E., Smith, R. H., van Dijk, W. W., Breugelmans, S. M., \& Zeelenberg, M. (2014). When envy leads to Schadenfreude. Cognition and Emotion, 29(6), 1007-1025. doi:10.1080/02699931.2014.961903

van de Ven, N., Zeelenberg, M., \& Pieters, R. (2009). Leveling up and down: The experiences of benign and malicious envy. Emotion, 9(3), 419-429. doi:10.1037/a0015669

van de Ven, N., Zeelenberg, M., \& Pieters, R. (2012). Appraisal patterns of envy and related emotions. Motivation and Emotion, 36(2), 195-204. doi:10.1007/ s11031-011-9235-8

Emerson Diógenes de Medeiros is an Adjunct Professor of the Universidade Federal do Piauí.

Ana Karla Silva Soares is an Adjunct Professor of the Universidade Federal de Mato Grosso do Sul.

Anderson Mesquita do Nascimento is a Ph.D. candidate from the Graduate Program of Social Psychology of the Universidade Federal da Paraíba.

Jéssica Bruna Santana Silva holds a M.S. in Cognitive Neuroscience and Behavior from Universidade Federal da Paraíba.

Valdiney Veloso Gouveia is a Full Professor of the Universidade Federal da Paraíba.

Received: Aug. 27, 2015

1st Revision: Jan. 17, 2016

Approved: Jan. 18, 2016

How to cite this article:

Medeiros, E. D., Soares, A. K. S., Nascimento, A. M., Silva, J. B. S., \& Gouveia, V. V. (2016). An ungrateful disposition: Psychometric properties of the Dispositional Envy Scale in Brazil. Paidéia (Ribeirão Preto), 26(65), 351-358. doi:10.1590/1982-43272665201605 